\title{
2.5 Gene banks that promote on-farm management through the reintroduction of local varieties in Brazil
}

\author{
Terezinha Aparecida Borges Dias, \\ Maria Aldete F. da Fonseca Ferreira, \\ Rosa Lia Barbieri, Flavia França Teixeira and \\ Sérgio Guilherme de Azevedo
}

\section{Background}

Brazil is rich in cultural diversity; its population is composed of different ethnic groups, including 219 different indigenous peoples and countless traditional communities. This diversity in population led to the application of diverse agricultural practices. However, rapid industrialization in agriculture has resulted in the loss of plant genetic resources (PGR) in farmers' fields, which in turn affects cultural diversity. This process has had a direct impact on the myths and rituals associated with agricultural practices, transforming their farming routines, and their livelihood in social and economic terms (Dias et al., 2007).

Approximately 35 years ago, the Brazilian Agricultural Research Corporation (Embrapa) set up a system for the conservation of genetic resources ex situ in Brazil. Its purpose was, and continues to be, to collect, exchange, characterize and conserve germplasm. Embrapa is aware of the growing demands of ex situ conservation and has been gradually organizing itself to respond to the needs of the agricultural sector. As conservation professionals who work with small-scale farming communities on the conservation of PGR, we focus our work at Embrapa on the need to promote social and technological innovation. We aim to motivate indigenous populations and traditional communities to continue their practices according to their local conditions and traditional knowledge, and thereby contribute to the conservation of PGR.

The Brazilian national system of genetic resource conservation is seeking pathways to contribute to the strategy of on-farm management (FAO, 2010) by supporting community biodiversity management (De Boef and Ogliari, 2007). One way of fulfilling this aim is to strengthen the interface between on-farm management and ex situ conservation strategies. In this chapter, we document our experiences as conservation professionals and curators of Embrapa gene banks in different locations in Brazil, on the reintroduction of maize, squash and sponge gourd accessions from gene banks to farmers' fields. These experiences illustrate how the relationship between ex situ conservation and on-farm management can enforce community biodiversity management. 


\section{Case 1: The reintroduction of traditional varieties of maize to the Krahô people}

Maize (Zea mays) was domesticated in Mesoamerica and introduced into South America by Pre-Columbian populations. Before the arrival of European colonizers, native populations in Brazil were already cultivating and selecting varieties of maize, generating a large genetic variability. The indigenous Krahô tribe comprises 2500 people, who live in 27 villages in the state of Tocantins. Ongoing conflicts with an expanding livestock and agricultural frontier, as well as inter-ethnic contacts, have resulted in the loss of indigenous maize varieties that were once part of Krahô traditional agriculture.

Krahô leaders are used to discussing important issues exhaustively and they remember a time when they cultivated abundant agrobiodiversity in their fields. They also remember the fact that they used to consume indigenous pohypey maize varieties during a ritual abstinence from certain foods, to promote their strength as Krahô people. In 1994, an extension agent informed the tribe about the existence of this indigenous variety, pohypey, in a gene bank. In 1995, the Krahô leaders visited the gene bank of the Embrapa Centre for Biotechnology and Genetic Resources (Embrapa-CENARGEN) in Brasília, accompanied by representatives of the National Foundation for Amerindian People (Fundação Nacional de Índio; FUNAI). During this visit, they identified different traditional pohypey varieties. These maize accessions had been collected by researchers in the state of Mato Grosso during the 1970s, in villages of the Xavante indigenous people. Following their visit, we provided the Krahô with small samples of $200 \mathrm{~g}$ of six varieties of indigenous pohypey maize. Through the reintroduction of these varieties we were able to contribute to a cultural revival in the villages, restoring traditional agricultural practices and associated myths and rituals.

In 1996, the Krahô returned small amounts of these varieties to the gene bank for storage. This return was something unheard of in the history of our gene bank at Embrapa-CENARGEN, and it helped to build a relationship based on trust between the Krahôs and Embrapa conservation professionals. Since then, together with the Krahô, we have been developing activities related to the strengthening of community biodiversity management (CBM). We have been engaged in CBM practices such as diversity kits and the identification of guardians of indigenous biodiversity. We join several other stakeholders in the organization of annual diversity fairs that facilitate the exchange of seed of traditional varieties. During this fair, we reward the villages that exhibit and share the largest number and diversity of varieties (Dias et al., 2007).

\section{Case 2: The reintroduction of traditional maize varieties to other indigenous populations}

It is interesting to note that the cycle that started with the collection of indigenous maize in the Xavante villages in the 1970s, its ex situ conservation and the provision of seed to the Krahô at a later stage, was completed when a Xavante leader visited our gene bank at Embrapa-CENARGEN in 2003. He did not resent the fact that we had been providing the Krahô people with their varieties but said that 
the Xavantes had also lost their varieties and wanted them back in their fields. Therefore, we multiplied the varieties and later were able to share seed with many Xavante villages.

Our activities with the Xavantes and the Krahô had national repercussions; today, other indigenous populations are seeking Embrapa gene banks, with the aim of recovering their varieties. Recently, at the request of indigenous leaders, the national maize gene bank, Embrapa National Agricultural Research Centre for Maize and Sorghum in Sete Lagoas, multiplied and sent seed of traditional varieties to the peoples of Bororo, Maxacali, Pataxó and Kaingang. This exemplifies the importance of interactions between ex situ conservation and on-farm management, because it led not only to the recovery of local varieties but also to the revitalization of indigenous people's rituals and myths, which is important for maintaining their culture and for maintaining plant genetic resources within communities.

\section{Case 3: Squash diversity and its association with ethnic diversity}

Thousands of years ago, five species of squash were domesticated in the Americas: Cucurbita argyrosperma, Cucurbita maxima, Cucurbita moschata, Cucurbita ficifolia and Cucurbita pepo. When the first Portuguese explorers disembarked on Brazilian land, five centuries ago, the indigenous people were cultivating several species and varieties of squash. For the Amerindians, squash was the third most important crop at that time, following cassava and maize. The Portuguese brought some of those squash to Europe, and the Spanish, having colonized other parts of the Americas, brought back local varieties of squash cultivated by the Aztecs, Mayas and Incas. Squash was a success. Its cultivation spread quickly through many countries, reaching Germany and Italy by the sixteenth century. When German and Italian immigrants arrived in Brazil in the nineteenth century, they brought seeds of their own squash varieties, in order to continue cultivating those that had already been incorporated into their culture three centuries earlier.

Nowadays, in many parts of Brazil, small-scale farmers keep their own local varieties of squash, selecting the types of fruit that please them the most. A small number of these farmers play a key role in the dynamics of on-farm management of varieties of several squash species. These farmers act as guardians of these PGR, and their function is to exchange them between relatives and neighbours and to pass them on from generation to generation. The squash guardians are directly associated with the cultural background of their communities.

Below, we share some examples of the association between species diversity and ethnic background in Brazilian people:

- Farmers of Portuguese origin in southern Brazil maintain local varieties of figleaf gourd (C. ficifolia), the fruits of which have a white and fibrous pulp, which is used in traditional Portuguese sweets recipes.

- Other farmers of Portuguese origin maintain local varieties of $C$. pepo, the fruits of which have hard skin and fibrous pulp, and are called mogangos.

- Afro-Brazilians, who live in communities called quilombola, have their own local 
varieties, especially mogangos (C. pepo) with its extremely hard skin and a long shelf life. They also maintain local varieties of $C$. maxima and $C$. moschata.

- Descendants of German immigrants maintain C. maxima and C. moschata. They also maintain ornamental varieties of $C$. pepo. German descendant farmers appreciate fruits that have intense colours and show a large variation in shape. The dried fruits are used in the decoration of their houses.

- Descendants of Italians prefer local varieties of $C$. maxima, the fruits of which are flat and have a firm flesh. They have an orange-coloured pulp. A common feature for all ethnic groups is that genetic erosion has had an increasing effect on their local varieties. This has also been affected by the disappearance of local cultures in culinary and ornamental traditions, caused by the industrialization of traditional agricultural systems, urban expansion and rural exodus, but also by changes in rural people's lifestyles (Heiden et al., 2007; Priori et al., 2010).

\section{Gase 4: The reintroduction of squash accessions to small-scale famers in southern Brazil}

Demand for seed of local varieties of squash by small-scale farmers in southern Brazil has increased in recent years. Since 2008, we have been making the seed of some accessions available during fairs dedicated to the exchange of seed of local varieties. In 2010, the gene bank of Embrapa Agricultural Research Centre for the Temperate Climate, in Pelotas, distributed three local varieties of squash to farmers in the municipality of São Lourenço do Sul. The farmers had donated the seed to the gene bank in 2005 and 2006 but had lost their varieties due to flooding in 2009. This restoration was extremely important for the community, because these varieties were part of the local food culture (Barbieri and Tempel, 2012).

\section{Case 5: The reintroduction of squash accessions to the Krahô people}

In 2006, we organized a training programme on methods of germplasm conservation. Participating Krahô leaders expressed their concern over the shortage of seed and ongoing loss of varieties of squash and pumpkin. On that occasion, we showed them images of the squash and pumpkin varieties maintained in the gene bank of Embrapa National Vegetable Research Centre, in Brasília, and provided them with seed of local squash varieties that they identified from the images. This provided the opportunity for a broader discussion on the existence, rarity, shortage and need for introduction and reintroduction of varieties. Together with the Krahô we identified 46 varieties of interest to the indigenous community. Accessions were identified and distributed.

\section{Case 6: The reintroduction of sponge gourd (Luffa cylindrica) accessions in Minas Gerais}

Sponge gourds are of great importance in small-scale agriculture because they are used in both human and animal diets. However, they have been facing genetic ero- 
sion in farmers' fields. In 2009, we started a project that aimed to promote on-farm management of local varieties of sponge gourds in the Furado da Onça community, in the north of Minas Gerais. We began the project by raising awareness through the establishment of a diversity block, as described by Shrestha et al. (Chapter 2.2), consisting of local varieties and germplasm received from our gene bank at EmbrapaCENARGEN. The diversity block was established in the fields of small-scale farmers, using their common management practices, thus without the use of inputs and chemicals. Seven local varieties and 13 gene bank accessions were observed and evaluated using a participatory approach. The criteria used by the farmers to evaluate the local varieties were identified and afterwards used for comparison. The farmers identified one local variety from the community and three accessions as promising. These varieties could be used directly by the farmers for the production of bath sponges and handicrafts (Fonseca Ferreira and De Azevedo, 2012).

\section{Conclusion}

The six cases presented in this chapter exemplify the importance of combining strategies of ex situ conservation and on-farm management in order to preserve the culture of using local crop varieties, shared by communities of indigenous and traditional people and small-scale farmers. Some of these communities have lost their traditional varieties and have been searching gene banks in order to restore them. This situation is a great challenge for us. We consider it our duty as curators to interact with guardians in a complementary and dynamic manner and feel that it is important to expand the dialogue and, through participatory planning, promote both the understanding of guardians in their original communities, and their recognition and inclusion in national strategies of genetic resource conservation. We consider that such actions, beyond our initial work to reintroduce germplasm in original communities, will contribute to the realization of community biodiversity management, empower these guardians and their communities, and promote the necessary integration of strategies of ex situ conservation and on-farm management. 